\title{
Foraging behaviour of larval cod (Gadus morhua) at low light intensities
}

\author{
K. W. Vollset $\cdot$ A. Folkvord $\cdot$ H. I. Browman
}

Received: 15 October 2010/ Accepted: 28 January 2011/Published online: 13 February 2011

(C) The Author(s) 2011. This article is published with open access at Springerlink.com

\begin{abstract}
The ability to forage at low light intensities can be of great importance for the survival of fish larvae in a pelagic environment. Three-dimensional silhouette imaging was used to observe larval cod foraging and swimming behaviour at three light intensities (dusk $\sim 1.36 \times 10^{-3} \mathrm{~W} / \mathrm{m}^{2}$, night $\sim 1.38 \times 10^{-4} \mathrm{~W} / \mathrm{m}^{2}$ and darkness $\sim 3.67 \times 10^{-6} \mathrm{~W} / \mathrm{m}^{2}$ ) at 4 different ages from 6 to 53 days post-hatch (dph). At $6 \mathrm{dph}$, active pursuit of prey was only observed under dusk conditions. Attacks, and frequent orientations, were observed from $26 \mathrm{dph}$ under night conditions. This was consistent with swimming behaviour which suggested that turn angles were the same under dusk and night conditions, but lower in darkness. Cod at $53 \mathrm{dph}$ attacked prey in darkness and turn angles were not different from those under other light conditions. This suggests that larvae are still able to feed at light intensities of $3.67 \times 10^{-6} \mathrm{~W} / \mathrm{m}^{2}$. We conclude that larval cod can maintain foraging behaviour under light intensities that correspond to night-time at depths at which they are observed in the field, at least if they encounter high-density patches of prey such as those that they would encounter at thin layers or fronts.
\end{abstract}

Communicated by D. Righton.

K. W. Vollset $(\triangle)$

Uni Miljø, LFI, PB 7810, 5020 Bergen, Norway

e-mail: Knut.vollset@uni.no

A. Folkvord

Department of Biology, University of Bergen,

5020 Bergen, Norway

H. I. Browman

Institute of Marine Research, Austevoll Research Station,

5392 Storeb $\varnothing$, Norway

\section{Introduction}

Foraging behaviour of most fish larvae is light dependent (Blaxter 1986). In nature, darkness is an important refuge from visual predators (Clark and Levy 1988), and the ability to see and capture prey in dim light can, therefore, be of great importance to larval survival. The general consensus is that 'the intake of food is limited by the hours of daylight available' (Blaxter 1969; Suthers and Sundby 1996). This conclusion is based upon the analysis of stomach fullness during diel cycles (Ellertsen et al. 1980), otolith growth increments (Suthers and Sundby 1996) and experimental work that relates feeding incidence to light intensity (e.g. Downing and Litvak 2001). Ellertsen et al. (1980) reported that larval cod ceases foraging below approximately $0.1-0.4$ lux and speculated that feeding during May in Lofoten, Norway, would be possible 20-24 h/day.

The ability of fish larvae to feed using visual cues is normally defined by a measure of visual acuity (Shand et al. 1999). This can be measured anatomically through, for example, photoreceptor counts and the focal length of the eye or behaviourally through measurements of reactive distance, reactive angle (e.g. Miller et al. 1993) or visual thresholds (e.g. Blaxter 1969 summarized in Browman et al. 1990). Although anatomical measures generally produce higher estimates (see Browman et al. 1990), behavioural measures-which can be considered more operational-suggest that the reactive distance (RD) of fish larvae rarely exceeds one body length (Miller et al. 1993; Ruzicka and Gallager 2006). At least for juveniles, RD and other measures of visual threshold typically decrease as light intensity decreases (e.g. Blaxter 1969; Meager et al. 2010). This suggests that the capacity for fish larvae to feed at low light intensity is limited. 
Visual acuity is coupled to encounter with prey through encounter rate models that typically apply a reactive distance dependent on light intensity, prey concentration, prey inherent contrast and water quality, together with a prey search space (Aksnes and Giske 1993; Aksnes and Utnepalm 1997; Fiksen et al. 1998). However, coupling direct behavioural measures of visual acuity with prey encounter has proven difficult, since knowledge of several aspects of visual feeding such as prey inherent contrast and prey search space is limited or non-existent (Garlbraith et al. 2004). Meanwhile, coupled biophysical models that attempt to predict either growth (e.g. Lough et al. 2005) or prey selection (e.g. Petrik et al. 2009) often apply a simple visual feeding threshold (e.g. no feeding below 0.1 lux) to fit field data that suggest that fish larvae have empty stomachs during the night. Below such a light threshold, fish larvae are also assumed to stop swimming, which could explain the often observed increased variance in vertical distribution at night (Lough et al. 1996). Swimming behaviour does indeed decrease with light intensity in larval cod (Puvanendran and Brown 2002). However, no direct observations have been made under light intensities that fish larvae experience at night.

Experiments that measure attack rate indirectly through, for example, stomach fullness suggest that gadoid larvae can capture prey under very low light intensities or even in complete darkness (Huse 1994; Downing and Litvak 2001; Downing 2002; Yoon et al. 2010). For cod, it has been suggested that the reason for this is accidental ingestion due to drinking during osmoregulation (Huse 1994). However, predators may also use other cues apart from vision to locate prey (e.g. mechanoreception and/or hearing), and before we make direct observations of fish larvae at low light intensities, we cannot conclude that they truly do stop actively pursuing prey during the dark night-time hours.

\section{Materials and methods}

\section{Larval rearing}

Eggs used in this experiment came from a brood stock of wild cod originating from Møre, Norway $\left(62^{\circ} \mathrm{N}\right)$. All eggs were from the same spawning event. Larvae were reared at $8^{\circ} \mathrm{C}$ in 500-1 tanks with natural zooplankton as prey, which was composed mainly of different species of copepods, copepodites and nauplii. Age 0 was defined as the day on which $50 \%$ of the eggs had hatched. For more details on the rearing protocol, see Vollset et al. (2009). Larvae were cultured at the High Technology Center in Bergen. On the morning before each trial, the larvae were transported to Austevoll Research Station, where the video observations took place. The larvae were taken from the rearing tank when some feeding had occurred $(\sim 0700 \mathrm{~h})$ and were not fed during transport or during acclimatization. The first trials started at around noon and ended between 1700 and 1900 h. Consequently, we expect that the larvae had empty stomachs and were highly motivated to feed (sensu Munk 1995). No mortality was observed after transport. Larvae were acclimatized to the water quality and temperature of the experimental tanks for at least $3 \mathrm{~h}$ in darkness.

\section{Imaging system and experimental set-up}

Three-dimensional silhouette imaging was used to observe larval cod, which allows fine scale behavioural observations with an image quality that is unaffected by ambient light levels. The system has been thoroughly described in Browman et al. (2003). In short, the system consists of two orthogonally oriented cameras with a far-red light-emitting diode (LED) placed at the focal point of a biconvex collimating lens, the output beam of which passes through an aquarium placed at the intersection.

Experiments were conducted at 6, 26, 34 and 53 days post-hatch (dph). The average weights of fish in the culture tanks at these ages were 57, 329, 894, 5,596 $\mu \mathrm{g}$, respectively, corresponding to approximately 4.5-, 7.5-, 10- and 16-mm standard length (SL) (Folkvord 2005). Before each trial, 30-50 larvae were added to 15 experimental aquaria $(20 \times 20 \times 20 \mathrm{~cm})$ (i.e. 5 replicates per treatment). At 6 and $34 \mathrm{dph}$, there were only enough larvae for three and four replicates per treatment, respectively. Twenty minutes before each replicate started, rotifers were added to the experimental chamber at an abundance of $3.8 \mathrm{ml}^{-1}$. At $53 \mathrm{dph}$, Artemia sp. was used at an abundance of $1.8 \mathrm{ml}^{-1}$. The temperature varied between 8.4 and $8.9^{\circ} \mathrm{C}$ throughout the trials, which was similar to the temperature in the rearing tanks (average $8.3^{\circ} \mathrm{C}$ ). Each age group was observed under three light settings (changed using quartz substrate neutral density filters applied to the collimated output of a 1,000-W Xenon arc lamp).

Light levels were defined as dusk, night and darkness according to the estimates of light intensity at a depth of $20 \mathrm{~m}$. Twenty meters corresponds to the lower range of distribution of first feeding cod larvae observed in the field during night-time (Ellertsen et al. 1980). Surface irradiance and attenuation coefficients (average $=0.12$ ) at the three light intensity settings were defined according to measurements in Lofoten, the main spawning area of north-east Arctic $\operatorname{cod}\left(67^{\circ} \mathrm{N}\right)$ (Fig. 1; Table 1) (S. Sundby, IMR, Bergen, Norway, unpublished data). Video recording started 5 min after the observation aquarium was placed at the intersection of the two lines of sight. The cameras recorded the midsection of the experimental aquaria (approximately $6 \times 8 \times 8 \mathrm{~cm})$ as explained in Browman et al. (2003). 
The recording was done for $30 \mathrm{~min}$ on S-VHS cassettes and then digitized using iQ Software (Andor Imaging ${ }^{\circledR}$ ).

Behavioural observations

An automated 3-D tracking software program was used to track individual larvae (for complete details on the Trackfish and Anapath software used, see Browman et al. 2003). Examples of tracks are shown in Fig. 2 for dusk and darkness settings, at 6 and $34 \mathrm{dph}$. The software extracts swim mode parameters for a saltatory predator: stop duration (s), move duration (s), move length $(\mathrm{mm})$, swimming speed $\left(\mathrm{mm} \mathrm{s}^{-1}\right)$, turn angles and activity (per cent of time spent actively moving). Each age group required slightly different program configuration settings to be able to capture the swimming behaviour of the larvae and post-larvae. In addition, manual observation of larval feeding behaviour was undertaken. Three Modal Action Patterns (MAPs) were defined, following from those described by Puvanendran and Brown (1998): Swim-Forward movement of larva through water column accomplished by caudal fin action, Orientation-Larva corrects body position with pelvic fins to orient body towards prey and Attack-coordinated movement and opening of mouth cavity to attempt to capture prey following an orientation. The prey targeted was

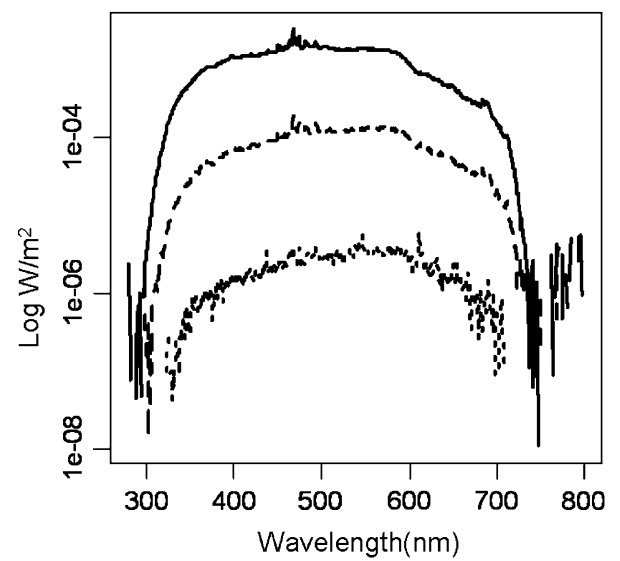

Fig. 1 Spectral irradiance of the three light settings dusk (solid line), night (dashed line) and darkness (dotted line) not identifiable for all observations due to the high concentration, and attacks and orientations were, therefore, assumed from larval posture. MAPs were collected from 5 different individuals during $1 \mathrm{~min}$ in each replicate. All observations were made between 5 and 10 min into each trial.

Data analysis

All analyses were done using R 2.2.1 (C). For each swim mode parameter from the automated tracking, and MAPs, the observations within each replicate were pooled for agespecific analysis of variance (ANOVA) with light as a factorial predictor variable. To conform to a normal distribution, all swim mode parameters were log-transformed $(+1)$ before pooling. A Tukey HSD post hoc test was applied to test between-group differences for both groups of behavioural observations. Violation of the normality and homoscedasticity assumptions was analysed by applying the Fligner-Killeen test in addition to diagnostic plots. When assumptions were violated, a non-parametric Kruskal-Wallis test was applied to test differences between the light treatments and a Bonferroni correction was applied to correct for multiple tests $\left(\alpha_{\mathrm{adj}}=\alpha / 3\right)$. Finally, to be able to compare feeding behaviour between ages, we calculated the fractional directional swimming (FDS), defined as per cent of movements that were not within $15^{\circ}$ angle in a forward direction in both the horizontal and vertical dimensions.

\section{Results}

At 6 dph, move duration was longer under dusk compared with night conditions, although not significantly different from darkness settings $\left(F_{2,5}=6.63, p=0.039\right.$, ANOVA; Table 2). The orientation rate MAP under dusk conditions was significantly higher than that for night and darkness $\left(F_{2,6}=6.82, p=0.028\right.$, ANOVA; Fig. $\left.3 \mathrm{~b}\right)$. There were observations of attacks under dusk conditions, but not under night or darkness conditions (Fig. 3c).

Table 1 Description of light conditions used in experiments with Atlantic cod (Gadus morhua) larvae

\begin{tabular}{llll}
\hline & Dusk & Night & Darkness \\
\hline Time of observation in field & $20: 00$ & $23: 00$ & $00: 00$ \\
Surface light measurements from field data in 1-5 April (lux) & 4.24 & 0.40 & 0.165 \\
Light at 20 meters according to $K=0.12$ & 0.38 & 0.036 & 0.015 \\
Light applied in experiment $\left(\mathrm{W} \cdot \mathrm{m}^{-2}\right.$ ) & $1.36 \times 10^{-3}$ & $1.36 \times 10^{-4}$ & $3.4 \times 10^{-6}$ \\
Light applied in experiment (converted to lux in white light) & $0.34-0.48$ & $0.034-0.049$ & $0.0009-0.0012$ \\
\hline
\end{tabular}

Conversions between $\mathrm{W} \cdot \mathrm{m}^{-2}$ are based on highest and lowest literature conversion factors that report conversion of lux in white light 
Fig. 2 Example of trajectories of Atlantic cod (Gadus morhua) larvae. Each 3-D visualization represents one replicate from 6 $(\mathbf{a}, \mathbf{c})$ and 35 (b, d) days posthatch at $\operatorname{dusk}(\mathbf{a}, \mathbf{b})$ and darkness (c, d) settings. The length scale indicated represents the dimensions of the viewing area
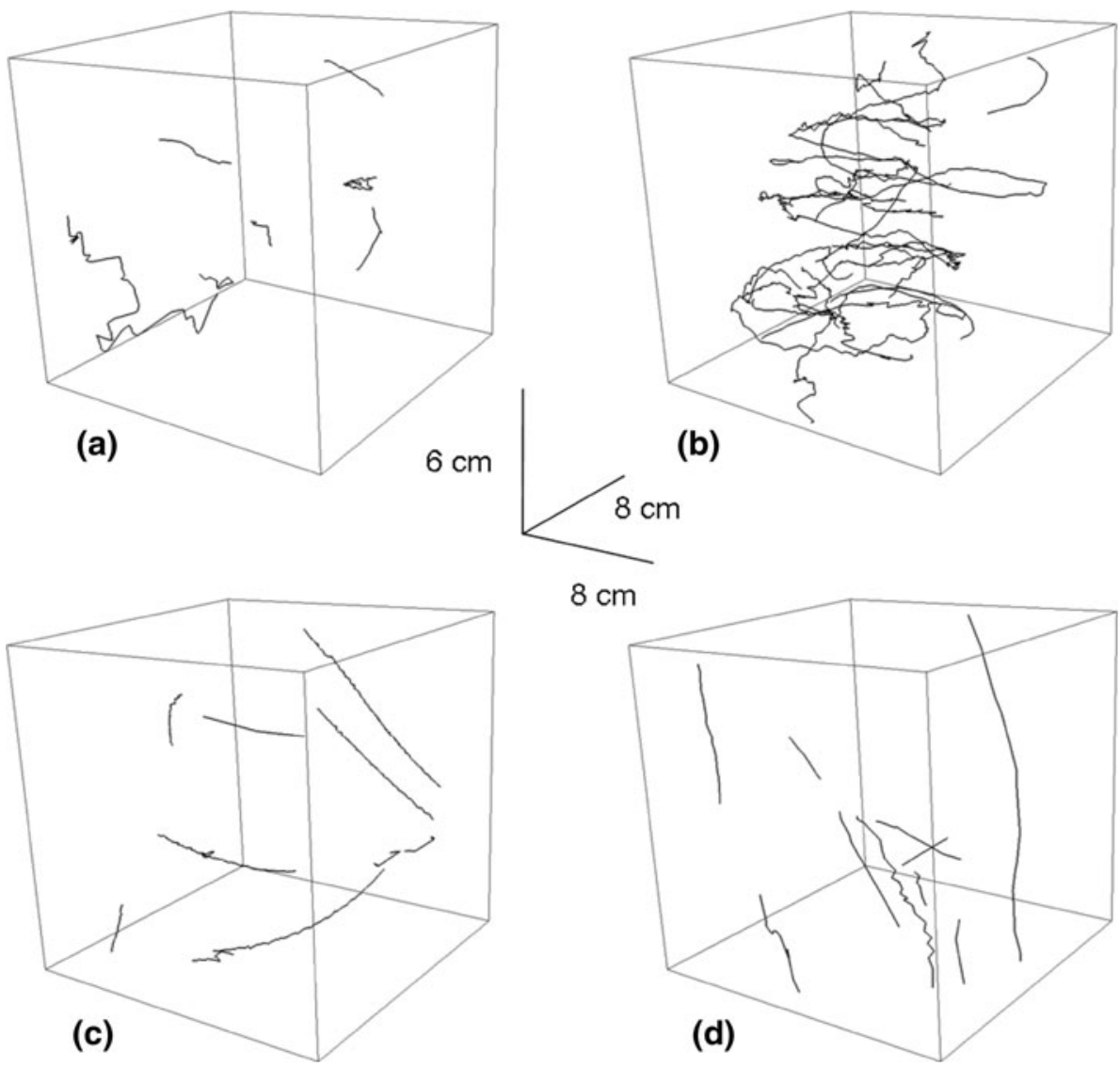

At $26 \mathrm{dph}$, there was a significantly lower average horizontal turn angle in darkness compared with night $\left(F_{2,11}, p=0.043\right.$, ANOVA; Table 2; Fig. 4). Swim rate $\left(F_{2,11}=16.18, p<0.01\right.$, ANOVA; Fig. $\left.4 \mathrm{a}\right)$ and orientation rate MAPs $\left(F_{2,11}=18.87, p<0.01\right.$, ANOVA; Fig. 3b) were significantly higher in dusk and night compared with darkness. Attacks were observed under dusk and night conditions but not under darkness (Fig. 3c).

At $34 \mathrm{dph}$, both horizontal $\left(F_{2,9}, F=4.41, p=0.046\right.$, ANOVA $)$ and vertical $\left(F_{2,9}, \quad F=6.64, \quad p=0.017\right.$, ANOVA) turn angles were lower in darkness (Table 2; Fig. 4). Swimming speed was also lower during night compared with darkness settings $\left(F_{2,9}=4.50, p=0.044\right.$, ANOVA; Table 1). There were no significant differences in the swim or orientation rate MAPs. Attacks were observed under night and dusk conditions but not in darkness. However, attacks were less frequent at $34 \mathrm{dph}$ than at 26 dph (Fig. 3c).

Neither horizontal nor vertical turn angles in darkness changed with light intensity at $53 \mathrm{dph}(p>0.05$, ANOVA; Table 1; Fig. 3). The swim rate MAP was lower in darkness compared with dusk $\left(F_{2,12}=5.02, p<0.05\right.$, ANOVA; Fig. 4), while there were no significant differences in the orientation MAP. Attacks were observed under all light conditions (Fig. 3c).
Fractional directional swimming (FDS) decreased in darkness for 6, 26 and 34 dph (Fig. 5). FDS did not change with light intensity for 53 dph larvae.

\section{Discussion}

Cod larvae continued to attack prey at light levels well below what is defined as limiting in foraging models (e.g. 0.1 lux, Lough et al. 2005). Cod larvae cease or reduce foraging behaviour at light levels of $3.4 \times 10^{-6} \mathrm{~W} / \mathrm{m}^{2}$ (darkness) at early stages $(6,26,34 \mathrm{dph})$, while $1.36 \times$ $10^{-4} \mathrm{~W} / \mathrm{m}^{2}$ (night) is sufficient for foraging behaviour from $26 \mathrm{dph}$, at least when prey density is high. At $53 \mathrm{dph}$, cod larvae forage at $3.4 \times 10^{-6} \mathrm{~W} / \mathrm{m}^{2}$ (darkness). This interpretation is supported by parameters extracted from swim paths (e.g. turn angles), the MAPs (including observations of attacks), and is further indicated by the reduction from dusk to darkness in FDS in all but the 53 dph larvae.

The effect of light on behaviour and growth in the early life stages of fishes has been studied extensively (e.g. Blaxter 1986; Batty 1987; Fiksen et al. 1998; Downing and Litvak 2001; Vollset et al. 2009). The development of new observation techniques, such as that applied here, allows us 
Table 2 Average and standard deviation (in parentheses) of values of swim mode parameters

\begin{tabular}{|c|c|c|c|c|}
\hline Swim mode parameter & Dusk $(n=3)$ & Night $(n=3)$ & Darkness $(n=3)$ & $p$ value \\
\hline \multicolumn{5}{|l|}{$6 d p h$} \\
\hline Stop duration (s) & $3.51(1.69)$ & $3.03(2.43)$ & $1.99(0.76)$ & 0.91 \\
\hline Move duration (s) & $0.54(0.05) \mathrm{a}$ & $0.43(0.05) \mathrm{b}$ & $0.52(0.02) \mathrm{ab}$ & 0.04 \\
\hline Move length (mm) & $3.41(0.57)$ & $2.59(0.36)$ & $3.32(0.67)$ & 0.52 \\
\hline Swimming speed $\left(\mathrm{mm} \mathrm{s}^{-1}\right)$ & $6.30(0.89)$ & $6.17(1.38)$ & $6.48(0.43)$ & 0.97 \\
\hline Turn angle $\left(\right.$ horizontal $\left.^{\circ}\right)$ & $56.37(14.58)$ & $67.14(32.01)$ & $21.13(4.64)$ & 0.12 \\
\hline Turn angle $\left(\right.$ vertical $\left.^{\circ}\right)$ & $12.44(2.60)$ & $26.77(13.48)$ & $8.80(6.07)$ & 0.08 \\
\hline \multirow[t]{2}{*}{ Per cent active $(\%)$} & $14.86(4.99)$ & $7.96(3.74)$ & $12.01(0.26)$ & 0.29 \\
\hline & Dusk $(n=5)$ & Night $(n=5)$ & Darkness $(n=5)$ & \\
\hline \multicolumn{5}{|l|}{$26 d p h$} \\
\hline Stop duration (s) & $1.64(0.12)$ & $2.09(0.58)$ & $1.53(0.63)$ & 0.09 \\
\hline Move duration (s) & $0.65(0.08)$ & $0.61(0.08)$ & $0.68(0.15)$ & 0.82 \\
\hline Move length (mm) & $3.31(0.47)$ & $3.28(0.49)$ & $3.85(1.33)$ & 0.75 \\
\hline Swimming speed $\left(\mathrm{mm} \mathrm{s}^{-1}\right)$ & $5.02(0.13)$ & $5.39(0.24)$ & $5.74(1.13)$ & 0.41 \\
\hline Turn angle $\left({ }^{\circ}\right)$ & $36.81(1.65) \mathrm{a}$ & $38.33(5.84) \mathrm{a}$ & $25.14(8.05) \mathrm{b}$ & 0.04 \\
\hline Turn angle $\left(\right.$ vertical $\left.^{\circ}\right)$ & $24.94(3.06)$ & $25.87(6.41)$ & $19.84(8.70)$ & $0.08 *$ \\
\hline \multirow[t]{2}{*}{ Per cent active $(\%)$} & $31.17(6.35)$ & $26.29(7.29)$ & $39.97(22.63)$ & 0.56 \\
\hline & Dusk $(n=4)$ & Night $(n=4)$ & Darkness $(n=4)$ & \\
\hline \multicolumn{5}{|l|}{$34 d p h$} \\
\hline Stop duration (s) & $2.13(0.43)$ & $4.46(2.30)$ & $1.75(0.87)$ & 0.07 \\
\hline Move duration (s) & $0.64(0.08)$ & $0.56(0.04)$ & $0.68(0.2)$ & 0.38 \\
\hline Move length (mm) & $3.48(0.61)$ & $2.74(0.27)$ & $4.02(1.77)$ & 0.15 \\
\hline Swimming speed $\left(\mathrm{mm} \mathrm{s}^{-1}\right)$ & $5.47(0.48) \mathrm{a}$ & $4.64(0.17) \mathrm{b}$ & $5.56(0.77) \mathrm{a}$ & 0.04 \\
\hline Turn angle $\left(\right.$ horizontal $\left.^{\circ}\right)$ & $44.61(13.55) \mathrm{a}$ & $42.26(6.26) \mathrm{a}$ & $21.46(9.32) \mathrm{b}$ & 0.04 \\
\hline Turn angle $\left(\right.$ vertical $\left.^{\circ}\right)$ & $24.85(8.19) \mathrm{a}$ & $27.28(6.21) \mathrm{a}$ & $13.74(4.54) b$ & 0.02 \\
\hline \multirow[t]{2}{*}{ Per cent active (\%) } & $30.50(8.31)$ & $16.71(6.18)$ & $32.95(19.96)$ & 0.07 \\
\hline & Dusk $(n=5)$ & Night $(n=5)$ & Darkness $(n=5)$ & \\
\hline \multicolumn{5}{|l|}{$53 d p h$} \\
\hline Stop duration (s) & $2.51(0.71)$ & $2.26(1.11)$ & $1.85(0.65)$ & 0.62 \\
\hline Move duration (s) & $0.56(0.07)$ & $0.57(0.03)$ & $0.55(0.05)$ & 0.75 \\
\hline Move length (mm) & $14.28(1.65)$ & $17.06(4.44)$ & $21.31(6.12)$ & 0.08 \\
\hline Swimming speed $\left(\mathrm{mm} \mathrm{s}^{-1}\right)$ & $24.84(4.76)$ & $31.58(9.99)$ & $39.74(10.73)$ & 0.07 \\
\hline Turn angle $\left(\right.$ horizontal $\left.^{\circ}\right)$ & $65.18(23.06)$ & $76.14(14.87)$ & $86.75(36.46)$ & 0.91 \\
\hline Turn angle (vertical) & $15.96(2.71)$ & $21.65(9.17)$ & $21.22(9.32)$ & 0.35 \\
\hline Per cent active $(\%)$ & $13.82(5.53)$ & $16.89(3.57)$ & $17.29(3.51)$ & 0.28 \\
\hline
\end{tabular}

$p$-values from ANOVA on log-transformed data are indicated if assumptions are met. Letters indicate significant differences between treatments $(p<0.05)$, where a denote the highest value. * indicates use of the non-parametric Kruskal-Wallis test with Bonferroni correction. $p$-value from $\mathrm{K}-\mathrm{W}$ test is from the comparison with the lowest $p$-value

to study these behaviours at lower light intensities than was previously possible (Browman et al. 2003). Earlier work has, for example, used stomach fullness as an indication of foraging success at different light intensities (Huse 1994; Downing and Litvak 2001; Downing 2002; Yoon et al. 2010). However, observations of gut fullness alone make it impossible to determine whether the intake is a consequence of active pursuit of prey or passive accidental ingestion (e.g. by gulping) (Huse 1994). The observations presented here show that cod continue to actively attack prey at light levels that are well below what has been defined as darkness for these developmental stages (e.g. Lough et al. 2005). Furthermore, the light intensity under night conditions applied in this experiment is typical of 
Fig. 3 Modal action patterns of a swimming movements, b orientations and $\mathbf{c}$ attacks according to light intensity of Atlantic cod (Gadus morhua) larvae. The three consecutive light levels are defined as darkness, night and dusk settings, respectively. The error bars represent 2 standard errors (a)
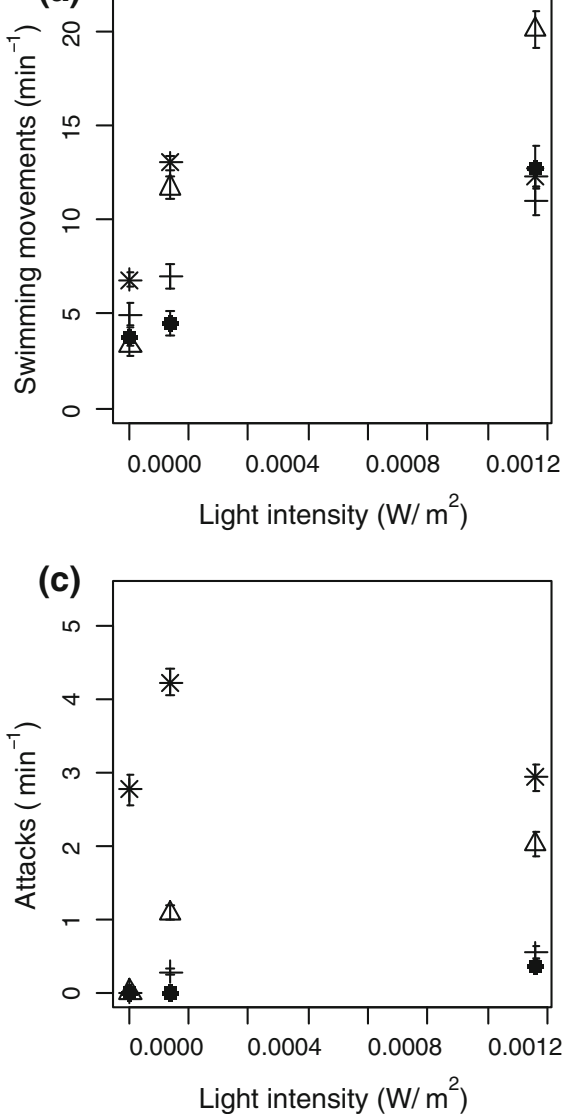

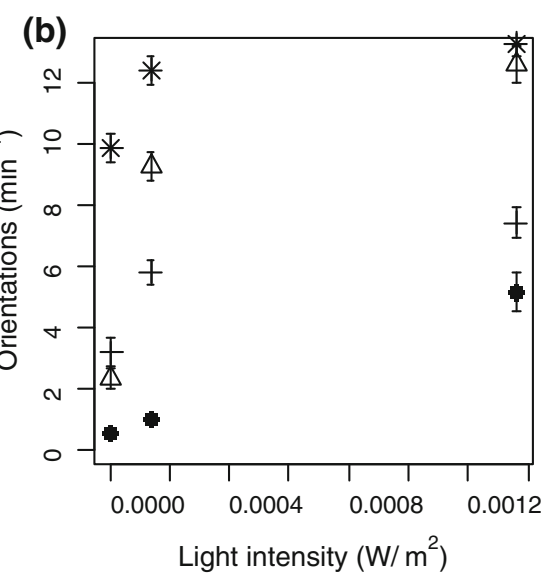

$\begin{array}{ll}- & 6 \mathrm{DPH} \\ \triangle & 26 \mathrm{DPH} \\ + & 34 \mathrm{DPH} \\ * & 53 \mathrm{DPH}\end{array}$ moonlit night, suggesting that cod larvae (from $26 \mathrm{dph}$ ) are capable of foraging at night in the wild.

Larval cod at $6 \mathrm{dph}$ attacked prey at $1.36 \times 10^{-3} \mathrm{~W} / \mathrm{m}^{2}$ ( 0.34-0.48 lux), $26 \mathrm{dph}$ larvae at $1.38 \times 10^{-4} \mathrm{~W} / \mathrm{m}^{2}$ ( $\sim 0.034-0.049$ lux $)$, while $53 \mathrm{dph}$ cod could attack prey even at light intensities of $3.67 \times 10^{-6} \mathrm{~W} / \mathrm{m}^{2}(\sim 0.0009-$ 0.0012 lux). In comparison, larval herring between 5 and 8 weeks has a visual feeding threshold between 0.18 and 0.025 lux (Blaxter 1967), larval plaice from 3 to 9 weeks old 1-0.01 lux (Blaxter 1969), juvenile herring 0.036-0.007 lux (Blaxter 1964) and anchovy from 10 to $15 \mathrm{~mm}$ long 0.0004 lux (Bagarinao and Hunter 1983). For pelagic stages of reef fish, Job and Shand (2001) reported that the visual feeding threshold of Apogon compressus, the most sensitive species they tested, increased from an average of ca. $0.22-1.2 \times 10^{-4} \mathrm{~W} / \mathrm{m}^{2}$, from 6 to $26 \mathrm{dph}$, respectively. As noted by Bagarinao and Hunter (1983), these studies used different measures of feeding, and therefore, direct comparison is difficult. Nonetheless, both larval and metamorphosed post-larval cod (53 dph) exhibited a behavioural visual sensitivity that is comparable to some of the most sensitive species so far tested.

Early-stage cod larvae are typical saltatory foragers that search for prey during pauses (MacKenzie and Kiøreboe 1995). Light has a direct effect on the encounter rate during these search events, as it affects the reaction distance of the larvae (Aksnes and Utne-Palm 1997). Therefore, light intensity should affect the search tactics of cod larvae. Saltatory foragers can optimize their prey encounters either by altering their move lengths, stop durations, swimming speed or turn angles (O'Brien et al. 1989). Ruzicka and Gallager (2006) suggested that feeding at very low light levels may be similar to foraging on small cryptic prey. Consequently, saltatory foraging behaviour predicts that net energy gain can be maximized by increasing stop duration and decreasing move duration between consecutive search volumes (O'Brien et al. 1989). Larval cod decrease swimming duration at lower light intensities (Puvanendran and Brown 2002). The decreased move duration between dusk and night conditions observed at $6 \mathrm{dph}$ is consistent with these predictions.

Cod larvae decreased turn angle and frequency of swimming movements under low light intensity at younger ages (6-34 dph), which coincided with lower frequencies of attacks and orientations. Hunter and Thomas (1974) found that dense patches of prey made anchovy larvae swim slower and turn more often which could be a mechanism to retain larvae in patches of food. Since light will decrease visual prey encounter in fish larvae, the mechanisms suggested for prey density could explain the 


\section{Dusk and Darkness}

\section{Dusk and Night}
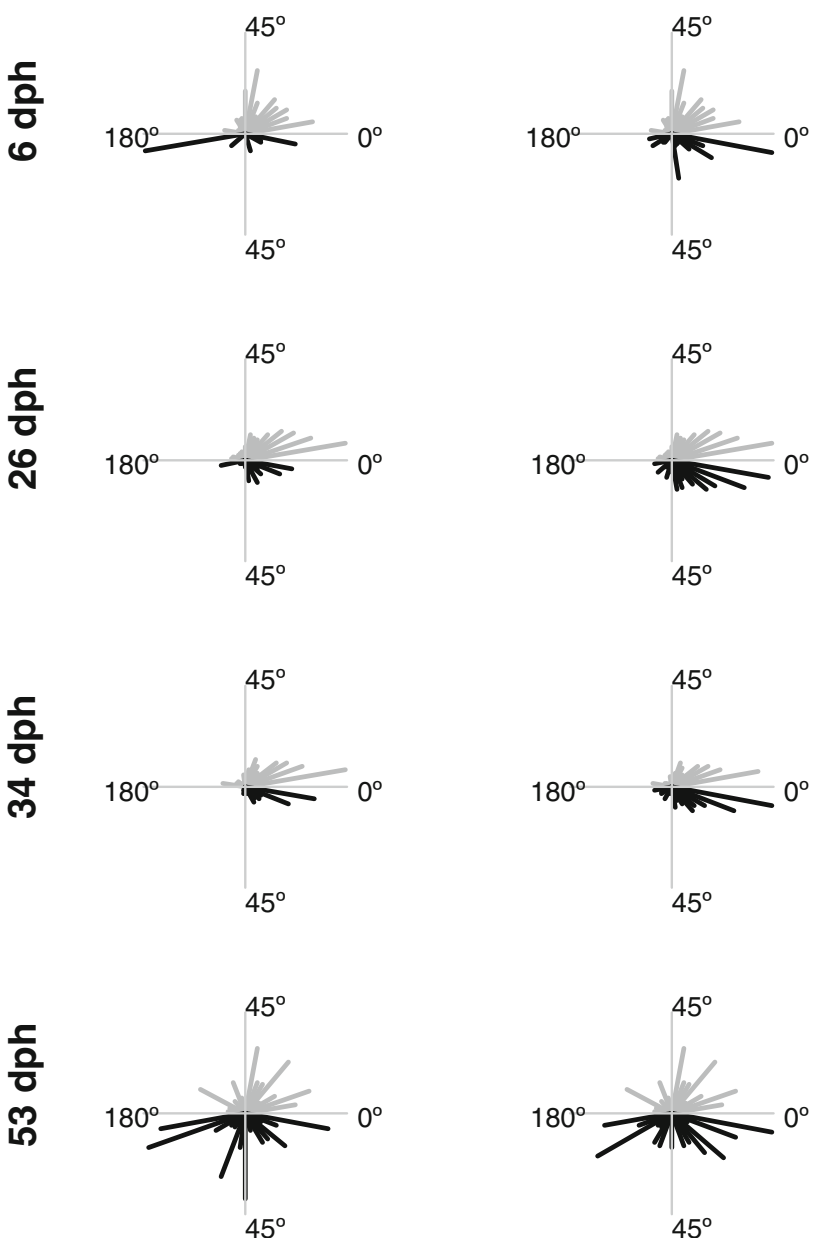

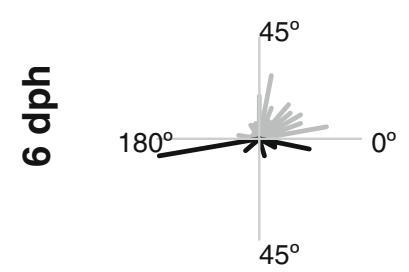

Fig. 4 Horizontal turn angles of Atlantic cod larvae plotted as star distribution plot on a $180^{\circ}$ axis where left and right turns are combined. To compare treatments, dusk settings are plotted both above darkness and night settings. Left: Dusk (grey) and Darkness (black) settings, right: Dusk (Grey) and Night (Black) settings

light intensity-related patterns of turn angle observed here. This is consistent with the theory of area-restricted search, which suggests that a forager should change turn angle according to the time-integrated information of prey encounter (Kareiva and Ordell 1987; Bell 1990).

The feeding behaviour of larval cod is also affected by olfactory cues (Døving et al. 1994; Yacoob et al. 2004). In experiments with very high concentrations of prey ( 3-10 prey $\mathrm{ml}^{-1}$, e.g. this study, Puvanendran and Brown 2002; Downing and Litvak 2001), the olfactory senses of the fish larvae are potentially highly stimulated. This could explain why foraging behaviour is maintained at low light intensity. A study of feeding behaviour in turbot (Champalbert and Direach-Boursier 1998) demonstrated

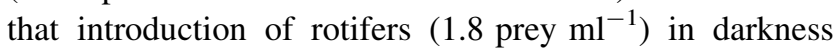

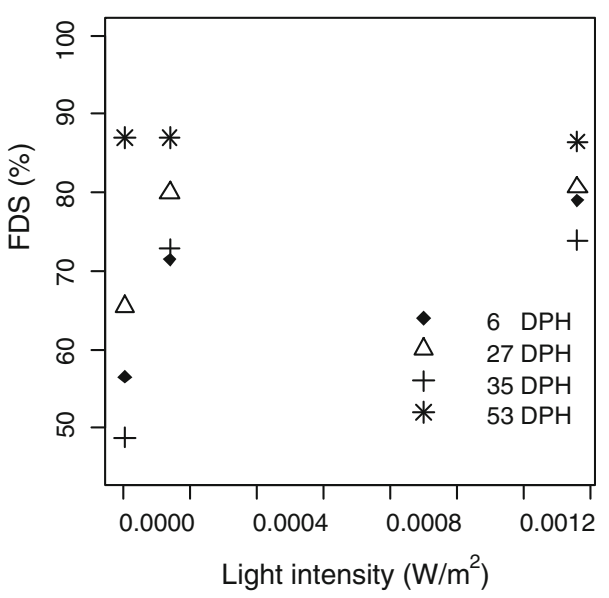

Fig. 5 Fractional directional swimming (per cent of movements outside $15^{\circ}$ angle in a forward direction in both the horizontal and vertical dimensions) as a function of light intensity. The three consecutive light levels are defined as darkness, night and dusk settings, respectively

would induce increase in activity that lasted for up to a few hours, indicating that larvae respond to prey presence in darkness. The movements of high concentrations of prey can also potentially stimulate mechanoreceptors and hearing. Such potential effects must be considered before concluding that the observed behavioural responses are entirely light dependent. However, considering that orientations and attacks were related to light intensity, it is most likely that vision is needed for successful pursuit of prey.

Cod larvae have a pure cone retina at hatching (Morrison 1993), while adults have both cones and rods (Anthony and Hawkins 1983). The recruitment of rods in marine fishes generally coincides with metamorphosis (Helvik et al. 2001; Evans and Browman 2004); this is probably why the post-larvae $(53 \mathrm{dph})$ in our experiments were able to feed at very low light intensity. Development of the retina is also affected by diet. For example, Bell et al. (1995) demonstrated that dietary deficiency of docosahexaenoic acid impaired vision at low light intensities in juvenile herring. The present experiment was conducted on larvae that were fed natural zooplankton, which is considered the gold standard with regard to dietary composition (Koedijk et al. 2010). This may be another reason for the high sensitivity to light exhibited by larvae in this experiment compared with earlier work on larvae reared on rotifers and enriched Artemia.

Larval cod are generally found at some depth in the field, ranging from ca. 5-50 $\mathrm{m}$ depending on the time of day, location, age and population (Ellertsen et al. 1980; Lough and Potter 1993). The spectral composition of light changes with depth (Jerlov 1976). In addition, the light scatters as a consequence of the particles in the water and becomes diffuse. This will affect several of the variables 
that determine predator-prey encounter rates (e.g. background light/contrast, beam attenuation). In this study, light was directed from above, while the background was the darkness of the experimental room. In addition, we delivered white light (Fig. 1) that only penetrated a water column that was a few centimetres deep and that contained no particles other than the prey. Therefore, the light environment in this experiment differs from what larvae experience in the field. Nonetheless, the data presented here suggest that cod larvae actively pursue prey at light intensities that they experience at night in the wild. This means that cod larvae forage significantly beyond the limits currently imposed in the individual-based models (IBM) of foraging and bioenergetics (Lough et al. 2005; Petrik et al. 2009).

Acknowledgments Thanks to Vibeke Lokøy and Nargis Islam for help with larval rearing and laboratory analysis. Thanks to Svein Sundby for providing measurements of light intensity from Lofoten. This work was partially funded by the University of Bergen. H. I. Browman and the behavioural research undertaken at the Austevoll Research Station were supported by the Norwegian Institute of Marine Research project 'Sensory biology and behaviour of early life stages'.

Open Access This article is distributed under the terms of the Creative Commons Attribution Noncommercial License which permits any noncommercial use, distribution, and reproduction in any medium, provided the original author(s) and source are credited.

\section{References}

Aksnes D, Giske J (1993) A theoretical-model of aquatic visual feeding. Ecol Model 67:233-250

Aksnes DL, Utne-Palm AC (1997) A revised model of visual range in fish. Sarsia 82:137-147

Anthony PD, Hawkins AD (1983) Spectral sensitivity of the cod, Gadus morhua L. Mar Behav Physiol 10:145-166

Bagarinao T, Hunter JR (1983) The visual feeding threshold and action spectrum of northern anchovy (Engraulis mordax) larvae. Calif Coop Ocea Fish Invest Rep 24:245-254

Batty RS (1987) Effect of light intensity on activity and foodsearching of larval herring, Clupea harengus: a laboratory study. Mar Biol 94:323-327

Bell WJ (1990) Searching behaviour. The behavioural ecology of finding resources. Chapman and Hall, New York

Bell MV, Batty RS, Dick JR, Fretwell K, Navarro JC, Sargent JR (1995) Dietary deficiency of docosahexaenoic acid impairs vision at low light intensities in juvenile herring (Clupea harengus L.). Lipids 30:443-449

Blaxter JHS (1964) Spectral sensitivity of the herring, Clupea harengus L. J Exp Biol 41:155-162

Blaxter JHS (1967) Visual thresholds and spectral sensitivity in herring larvae. J Exp Biol 48:39-53

Blaxter JHS (1969) Visual thresholds and spectral sensitivity of flatfish larvae. J Exp Biol 51:221-230

Blaxter JHS (1986) Development of sense organs and behaviour of teleost larvae with special reference to feeding and predator avoidance. Trans Am Fish Soc 115:98-115
Browman HI, Gordon WC, Evans BI, O’Brien WJ (1990) Correlation between histological and behavioral measures of visual acuity in a zooplanktivorous fish, the white crappie (Pomoxis annularis). Brain Behav Evol 35:85-97

Browman HI, St-Pierre JF, Skiftesvik AB, Racca RG (2003) Behaviour of Atlantic cod (Gadus morhua) larvae: an attempt to link maternal condition with larval quality. In: Browman HI, Skiftesvik AB (eds) The big fish bang. Proceedings of the 26th annual larval fish conference, pp 71-95

Champalbert G, Direach-Boursier LL (1998) Influence of light and feeding conditions on swimming activity rhythms of larval and juvenile turbot Scophthalmus maximus L.: an experimental study. J Sea Res 40:333-345

Clark CW, Levy DA (1988) Diel vertical migrations by juvenile sockeye salmon and the antipredation window. Am Nat 131:271-290

Døving KB, Mårstøl M, Andersen JR, Knutsen JA (1994) Experimental evidence of chemokinesis in newly hatched cod larvae (Gadus morhua L.). Mar Biol 120:51-358

Downing G (2002) Impact of spectral composition on larval haddock, Melanogrammus aeglefinus L., growth and survival. Aquacult Res 33:251-259

Downing G, Litvak MK (2001) The effect of light intensity and spectrum on the incidence of first feeding by larval haddock. J Fish Biol 59:1566-1578

Ellertsen B, Moksness E, Solemdal P, Stromme T, Tilseth S, Westgard T, Oiestad V (1980) Some biological aspects of cod larvae (Gadus morhuи L.). Fisk Dir Skr Ser Hav Unders 17:29-47

Evans BI, Browman HI (2004) Variation in the development of the fish retina. Am Fish Soc Symp 40:145-166

Fiksen $\varnothing$, Utne ACW, Aksnes DL, Elane K, Helvik JV, Sundby S (1998) Modelling the influence of light, turbulence and ontogeny on ingestion rates in larval cod and herring. Fish Ocean $7: 355-363$

Folkvord A (2005) Comparison of size-at-age of larval cod (Gadus morhua L.) from different populations based on size- and temperature-dependent models. Can J Fish Aquat Sci 62:10371052

Garlbraith PS, Browman HI, Racca RG, Skiftesvik AB, Saint-Pierre JF (2004) Effect of turbulence on the energetics of foraging in Atlantic cod Gadus morhua larvae. Mar Ecol Prog Ser 281:241-257

Helvik JV, Drivenes O, Næss TH, Fjose A, Seo HC (2001) Molecular cloning and characterization of five opsin genes from the marine flatfish Atlantic halibut (Hippoglossus hippoglossus). Vis Neurosci 18:767-780

Hunter JR, Thomas GL (1974) Effect of prey distribution and density on the searching and feeding behaviour of larval anchovy Engraulis mordax Girard. In: Blaxter JHS (ed) The early life history of fish. Springer, Berlin, pp 559-574

Huse I (1994) Feeding at different illumination levels in larvae of three marine teleost species: cod, Gadus morhua L., plaice, Pleuronectus platessa L., and turbot, Scophthalmus maximus L. Aquac Fish Manag 25:687-695

Jerlov NG (1976) Marine optics. Elsevier, Amsterdam

Job SD, Shand D (2001) Spectral sensitivity of larval and juvenile coral reef fishes: implications for feeding in a variable light environment. Mar Ecol Prog Ser 214:267-277

Kareiva P, Ordell G (1987) Swarms of predators exhibit "preytaxis" if individual predators use area-restricted search. Am Nat 130:233-270

Koedijk R, Folkvord A, Foss A, Pittman K, Stefansson SO, Handeland S, Imsland A (2010) The influence of first feeding diet on the Atlantic cod (Gadus morhua L.) phenotype; survival, development and long term consequences for growth. J Fish Biol 77:1-19 
Lough RG, Potter DC (1993) Vertical-distribution patterns and diel migrations of larval and juvenile haddock Melanogrammus aeglefinus and atlantic cod Gadus morhua on Georges Bank. Fish Bull 91:281-303

Lough RG, Caldarone EM, Rotunno TK, Broughton EA, Burns BR, Buckley LJ (1996) Vertical distribution of cod and haddock eggs and larvae, feeding and condition in stratified and mixed waters on southern Georges Bank, May 1992. Deep Sea Res II 43:1875-1904

Lough RG, Buckley LJ, Werner FE, Quinlan JA, Pehrson Edwards K (2005) general biophysical model of larval cod (Gadus morhua) growth applied to populations on Georges Bank. Fish Oceanogr 14:241-262

MacKenzie BR, Kiøreboe T (1995) Encounter rates and swimming behavior of pause-travel and cruise larval fish predators in calm and turbulent laboratory environments. Limonol Oceanogr 40:1278-1289

Meager JJ, Moberg O, Strand E, Utne-Palm AC (2010) Effects of light intensity on visual prey detection by juvenile Atlantic cod (Gadus morhua L.). Mar Fresh Behav Physiol 43:99-108

Miller TJ, Crowder LB, Rice JA (1993) Ontogenetic changes in behavioural and histological measures of visual acuity. Environ Biol Fish 37:1-8

Morrison CM (1993) Histology of the Atlantic cod, Gadus morhua: an atlas. Part four: eleutheroembryo and larva. Can Spec Publ Fish Aquat Sci 119:1-496

Munk P (1995) Foraging behaviour of larval cod (Gadus morhua) influenced by prey density and hunger. Mar Biol 122:205-212

O'Brien JW, Evans BI, Browman HI (1989) Flexible search tactics and efficient foraging in saltatory searching animals. Oecologia $80: 100-110$
Petrik CM, Kristiansen T, Lough RG, Davis CS (2009) Prey selection by larval haddock and cod on copepods with species-specific behavior: an individual-based model analysis. Mar Ecol Prog Ser 396:123-143

Puvanendran P, Brown JA (1998) Effect of light intensity on the foraging and growth of Atlantic cod larvae: interpopulation difference? Mar Ecol Prog Ser 167:207-214

Puvanendran V, Brown JA (2002) Foraging, growth and survival of Atlantic cod larvae reared in different light intensities and photoperiods. Aquaculture 214:1-4

Ruzicka JJ, Gallager SM (2006) The saltatory search behavior of larval cod (Gadus morhua). Deep Sea Res II 53:2735-2757

Shand J, Døving KB, Collin SP (1999) Optics of the developing eye: comparisons of Matthiessen's ratio and the focal length of the lens in the black bream Acanthopagrus butcheri (Sparidae, Teleostei). Vision Res 39:1071-1078

Suthers IM, Sundby S (1996) Role of the midnight sun: comparative growth of pelagic juvenile cod (Gadus morhua) from the ArctoNorwegian and a Nova Scotian stock. ICES J Mar Sci 53:827-836

Vollset KW, Fiksen $\varnothing$, Folkvord A (2009) Vertical distribution of larval cod (Gadus morhua) in experimental temperature gradients. J Exp Mar Biol Ecol 379:16-22

Yacoob SY, Browman HI, Jensen PA (2004) Electroencephalogram recordings from the olfactory bulb of juvenile (0 year) Atlantic cod in response to amino acids. J Fish Biol 65:1657-1664

Yoon H, Hwang J, Choi S (2010) Effect of light intensity on first feeding of the chub mackerel Scomber japonicus larvae. Anim Cell Syst 14:125-128 